\title{
Identification of Promising IRRI CMS Lines through OCR in Chhattisgarh, India
}

\author{
Satyapal Singh ${ }^{1^{*}}$, Deepak Sharma ${ }^{1}$, Ritesh $\operatorname{Singh}^{2}$, Jauhar Ali $^{3}$ and Deepak Gauraha ${ }^{1}$ \\ ${ }^{1}$ Department of Genetics and Plant Breeding, ${ }^{2}$ Department of Agronomy, \\ College of Agriculture, Indira Gandhi Krishi Vishwavidyalya, Raipur, Chhattisgarh, India \\ ${ }^{3}$ International Rice Research Institute, Manila, Philippines \\ *Corresponding author
}

\begin{abstract}
A B S T R A C T
The investigation was carried out to estimate the component of genetic variability and associated parameters among 12 IRRI CMS lines and evaluated for morphological characteristics that influence outcrossing rate in hybrid rice. There was a marked variation in out crossing rate of CMS lines ranging from $18 \%$ to $45 \%$ under uniform weather conditions for all the CMS lines. Variation in plant height, number of panicle per plant and panicle length appeared to have an influence on outcrossing rate. Phenotypic acceptability, plant height $(\mathrm{cm})$, days to $50 \%$ flowering, Panicles per plant and out crossing rate (OCR) here assessed. IR 102760A found best CMS lines with highest OCR \% and yield per plant among $12 \mathrm{CMS}$ lines. It means such type of CMS line will be suitable for hybrid seed program and profitable in hybrid rice seed business followed by IR 105688A, IR 102757A, IR 105687A and IR 102571A may also be a promising CMS lines for hybrid rice seed program and heterosis breeding since they possess critical outcrossing traits such as panicles per plant and panicle length. Plant height, panicle per plant and plant length, had moderate heritability with high genetic advance expected in the subsequent generation revealed role of additive gene action. The GCV and PCV somewhat varied from each other for most of the characters studied showed, there is no environmental influence on these traits. Genotypic correlation coefficient were higher than strong relation to phenotypic correlation coefficient indicated high relation among the studied character.
\end{abstract}

\section{Introduction}

Rice is the staple food for the millions of people in the world. Hybrid rice technology is considered as one of the promising, practical, sustainable and eco-friendly options to break the yield ceiling in rice (Sheeba et al., 2009). The use of hybrid rice varieties on commercial scale utilizing male sterility and fertility restoration system has proved to be one of the mile stones in the history of rice improvement. The hybrid rice technology now in operation, aims at yield increment through higher exploitable heterosis levels (Islam et al., 2010).

In three line system of hybrid rice variety development system, three lines, A, B and R are required. A line is the cytoplasm-genetic male sterile line where the male sterility is jointly controlled by recessive nuclear gene and sterile cytoplasm. 
B-line is isogenic line of A-line, only difference in male sterility and fertility. R-line possesses fertility restoration gene (Islam et al., 2014). A commercial A-line is characterized by the absence of pollen grains or rudimentary pollens, agronomically superiority, stable sterility, wide regeneration spectrum, abortive anther and highly synchronized (Yuan et al., 1998). B line is the maintainer line characterized by normal anthers, functional pollens and seed setting on selfing. While normal anthers, functional pollens, abundant pollen producing capacity, strong restoring ability, good combining ability, high out crossing rate, and genetically diverse from CMS line (Islam et al., 2009 and Mian et al., 2010) are the main characteristics of R-line. It is 30 years since the first commercial release of hybrid rice. Plant cytoplasmic male sterility (CMS), a maternally inherited trait that prevents plants from producing functional pollen, has been identified in many higher plants, including rice, cotton, maize, and sorghum. CMS restorer systems have been widely exploited to produce hybrids that outperform their inbred parents in yield, biomass, or other traits.

The discovery of CMS in rice suggested that breeding could develop a commercially viable $F_{1}$ hybrid (Athwal and Virmani, 1972). The most promising hybrids yielded $20-30 \%$ (Lin and Yuan, 1980) and 15-20\% (Yuan, 1998) higher than the best conventional rice varieties. Therefore, to break through the present yield ceiling of semi dwarf modern varieties, hybrid rice seems to be an attractive viable alternative. It is urgently needed to develop parental lines viz. A lines, B lines and $\mathrm{R}$ lines for developing hybrid rice varieties, with resistance to disease or environmental changes. Cytoplasmic genetic male sterility (CGMS) resulting from nuclearcytoplasmic interaction has been commercially exploited for the production of
$F_{1}$ hybrid seed in rice. Iso-cytoplasmic restorers have been developed successfully for many CMS lines. CMS sources are distinguished from one another on the basis of the fertility of crosses involving CMS lines and restorers (Eusebio et al., 2002).

\section{Materials and Methods}

The present study and experiment was conducted at university research field cum instructional farm, hybrid rice section, department of Genetics and Plant Breeding, Indira Gandhi Krishi Vishwavidyalaya, Raipur, Chhattisgarh, India. It is situated at $21^{\circ} 16^{\prime} \mathrm{N}$ Latitude and $81^{\circ} 36^{\prime}$ 'E longitude at an altitude of 289.60 meters above mean sea level.12 WA CMS lines collected from IRRI, Philippines, Manila was grown during summer rice season of 2020. The experiment was conducted as randomized complete block design with two replications with inter-row and intra row spacing of $20 \mathrm{~cm}$.

All recommended agronomical practices were followed to raise the ideal crop stand.13 important traits like Days to $50 \%$ flowering, Plant Height, effective tillers per plant, panicle length, number of fertile spikelets per panicle, sterile spikelet per plant, Outcrossing rate, Biological weight, grain weight were recorded.

Analysis of variance (ANOVA) was conducted and variance within the population was determined along with important parameters like Genotypic Coefficient of Variability (GCV), Phenotypic Coefficient of Variability (PCV), Heritability \%, Genetic Advance (GA)\% were calculated. Correlation coefficient analysis in order to determine the genotypic and phenotypic correlation among the 13 traits was also conducted. Outcrossing rate (OCR \%) calculated by given equation and scale suggested in IRRI hybrid rice breeding manual (Virmani et al., 1997). 


\section{Outcrossing rate (OCR\%)}

It refers to extent of seed set on open pollinated panicles which is expressed in percentage.

OCR $(\%)=\frac{\text { No.of Filled Spikelets }}{\text { Total no.of spikelets }} X 100$

\begin{tabular}{|l|l|}
\hline Scale & $\begin{array}{l}\text { No. of seed set on open } \\
\text { pollinated panicle }\end{array}$ \\
\hline $\mathbf{1}$ & $>35$ \\
\hline $\mathbf{3}$ & $25-35$ \\
\hline $\mathbf{5}$ & $15-25$ \\
\hline $\mathbf{7}$ & $5-15$ \\
\hline $\mathbf{9}$ & $0-5$ \\
\hline
\end{tabular}

\section{Results and Discussion}

Cytoplasmic male sterility (CMS) lines in hybrid rice breeding programme, outcrossing rate is one of the most important characteristics hybrid seed production program. Analysis of genotypic and phenotypic coefficient of variation was not remarkably varied from each other for most of the character studied.

Analysis of genotypic and phenotypic coefficient of variation was not remarkably varied from each other for most of the characters studied, indicated negligible environmental influence on these traits. Variation exhibited highly significant differences among the CMS lines for the characters studied.

\section{Assessment based on mean value}

The study evinced that mean values indicated considerable variation for all the traits under study revealing scope of development of CMS lines with good outcrossing ability (Table 1). Days to $50 \%$ flowering, No. of panicles per plant, panicle length and Out crossing rate (\%) were expressed differentially in different CMS lines. Duration of CMS lines ranged from 132 to 147 days. CMS line IR 102757A had the shortest growth duration and IR 102760A had the highest duration. Days to flowering ranged from 112 to 127 days. The CMS line IR $102760 \mathrm{~A}$ required the longest time for days to flowering that was significantly different from rest of the CMS lines. The CMS line IR 102758A showed the highest plant height (97 $\mathrm{cm}$.) as compared to others, followed by CMS lines, IR 102571A and IR 102573A. The other CMS lines exhibited medium short stature, such variations were also observed earlier by Hasan et al., (2011). The genotypes were mostly dwarf to semi dwarf in nature with an average height of $85.44 \mathrm{~cm}$.

The maximum number of productive tillers per plant was recorded in the CMSIR 102571A followed by IR 102572A and IR 102757A. Panicle length ranged from 21 to $28 \mathrm{~cm}$. The longest panicle length was found in CMS line IR 68897A followed by IR 102758A. OCR \% was found to be in a range of $18 \%$ to $45.02 \%$ with an average out crossing $\%$ of $32.21 \%$.

Out crossing \% which is the most vital trait for consideration was found to be highest in IR $102760 \mathrm{~A}$ (45.02\%) which is $>35 \%$. Sheeba et al., (2006) and Virmani et al., 1989) reported similar results on this traits.Five CMS lines performing highest scorer $42 \%$ (Fig 1) in outcrossing ratio (25$35 \%)$ out of 12 CMS lines and scored one (1) according Virmani et al., (1997). The maximum coefficient of variation of OCR $8.16 \%$ indicated that out crossing rate was remarkably varied in the trial that could be minimized by statistical inference. Laut $e t$ al., 1994) reported significant difference in outcrossing potential among the CMS lines. Most of the tested CMS lines were found stable in respect of pollen sterility (Table 1). 
Assessment based on coefficient of variation, heritability and genetic advance

Genetic variability analysis revealed narrow difference between phenotypic coefficient of variation (PCV) and genotypic coefficient of variation $(\mathrm{GCV})$ for all the characters indicating the reliability of PCV as a measure of GCV.

In general the PCV were higher than the corresponding GCV (Table 2) and GCV provides a mean to study the genetic variability generated in quantitative characters. The genotypic and phenotypic coefficient of variations, broad sense heritability and genetic advance in percent of mean are presented in Table 2.

Genotypic coefficient of variation (GCV) ranged from 35.61 (Days to Flowering)to 225.66 (No. of sterile spikelet) and phenotypic coefficient of variation (PCV) ranged from 187.14 (Flag leaf length) to 245.81 (Fertile spikelet). The genotypic and phenotypic coefficient of variations remarkably differ in the tested entry for most of the characters studied, indicating maximum environmental influence on these traits (Similarly find by Singh et al., 2015).

Sterile spikelet showed high magnitudes of heritability and high genetic advances but low variations among the CMS lines. Maurya and Singh, (1986) reported that high heritability along with high genetic advance could be the effect for high selection response in low land rice. Plant height exhibited high heritability and moderate genetic advance but the difference between GCV and PCV Table 2.

Genetics parameter for different characters of 12 CMS lines was minimum in Days to flowering, it means highly influenced by environment. Out crossing rate had appreciable heritability and genetic advance expected in the next generation due to high genetic advance with high heritability and selection may be effective on the basis of OCR \%. In general, genotypic correlation coefficients were higher than corresponding phenotypic correlation coefficients, suggesting strong inherent relation among all the characters.

The height positive significant association both at genotypic and phenotypic levels with sterile spikelet of CMS lines and genotypic level with outcrossing rate in hybrid rice breeding. Panicles per plant had positive and highly significant association with panicle length. Hasan et al., (1987) found plant height had positive and significant association with panicle length.

Dhanraj et al., (1987) and found positive correlation between days to $50 \%$ flowering with plant height and effective tillers per plant. Panicles per plant positively and highly significantly genotypic correlation associated with Out Crossing Rate (OCR). Virmani, (1994) and Sharma, (1995) found total number of spikelet per panicle with higher outcrossing rate. Panicle length showed positive and highly genotypic correlation significant association with Out Crossing Rate (OCR). Abeysekera et al., 2003).

However, characteristics like plant height, panicles per plant and panicle length should be considered important in enhancing out crossing rate category which showed high performance of one or several characteristics associated with outcrossing. Among the eight CMS lines evaluated, IR 102760A, IR 105688A, IR 102757A, IR 105687A and IR 102571A may be exploited for heterosis breeding since they possess critical outcrossing traits such as OCR\% (>35\%), No. of panicles per plant and panicle length. IR 102760A showed highest yield per plant (20.77 gm.) with highest OCR \% (45.02). 
Table.1 Morphological characteristics and OCR \% in IRRI WA CMS lines

\begin{tabular}{|c|c|c|c|c|c|c|c|c|c|c|c|c|c|}
\hline CMS Line & $\begin{array}{c}\text { Days to } \\
\text { Flowering }\end{array}$ & $\begin{array}{l}\text { No. of } \\
\text { Tillers } \\
\text { /plant }\end{array}$ & $\begin{array}{c}\text { Productive } \\
\text { Tillers } \\
\text { /plant }\end{array}$ & $\begin{array}{c}\text { Plant } \\
\text { Height }\end{array}$ & $\begin{array}{c}\text { Flag } \\
\text { Leaf } \\
\text { Length } \\
\text { (cm) }\end{array}$ & $\begin{array}{c}\text { Flag } \\
\text { Leaf } \\
\text { Width }\end{array}$ & $\begin{array}{c}\text { Panicle } \\
\text { Length } \\
\text { (cm) }\end{array}$ & $\begin{array}{l}\text { No. of } \\
\text { Panicle }\end{array}$ & $\begin{array}{c}\text { Fertile } \\
\text { Spikelet }\end{array}$ & $\begin{array}{c}\text { Sterile } \\
\text { spikelet }\end{array}$ & $\begin{array}{c}\text { OCR } \\
(\%\end{array}$ & $\begin{array}{c}\text { Biological } \\
\text { weight } \\
\text { (gm) }\end{array}$ & $\begin{array}{c}\text { Grain } \\
\text { weight } \\
\text { (gm) }\end{array}$ \\
\hline & 1 & 2 & 3 & 4 & 5 & 6 & 7 & 8 & 9 & 10 & 11 & 12 & 13 \\
\hline IR 93558A & 117.00 & 13.50 & 15.00 & 82.76 & 33.79 & 1.30 & 21.18 & 17.00 & 376.00 & 983.50 & 27.68 & 31.50 & 8.17 \\
\hline IR 105687A & 114.50 & 18.00 & 14.00 & 83.19 & 27.63 & 1.38 & 23.68 & 17.05 & 929.50 & 1431.00 & 39.70 & 37.00 & 19.10 \\
\hline IR 102760A & 126.50 & 22.00 & 17.50 & 82.53 & 24.04 & 1.42 & 23.79 & 21.88 & 958.50 & 1170.00 & 45.02 & 55.50 & 20.77 \\
\hline IR 102758A & 123.50 & 14.50 & 12.50 & 96.51 & 25.98 & 1.32 & 27.88 & 12.14 & 358.00 & 914.00 & 28.13 & 32.00 & 7.37 \\
\hline IR 102573A & 116.00 & 16.50 & 12.50 & 87.58 & 27.97 & 1.21 & 24.28 & 12.03 & 262.50 & 1200.50 & 18.00 & 40.00 & 10.70 \\
\hline IR 102572A & 113.50 & 19.00 & 22.00 & 74.06 & 24.74 & 1.42 & 21.28 & 18.21 & 341.50 & 1165.50 & 22.67 & 39.00 & 4.24 \\
\hline IR 102571A & 121.00 & 24.00 & 25.00 & 92.04 & 27.35 & 1.50 & 25.81 & 21.03 & 836.50 & 1447.50 & 36.62 & 51.50 & 19.05 \\
\hline IR 102569A & 119.00 & 22.50 & 21.00 & 80.93 & 21.24 & 1.30 & 20.53 & 22.21 & 541.00 & 1581.50 & 25.49 & 51.50 & 12.88 \\
\hline IR 105688A & 123.00 & 16.50 & 14.50 & 81.81 & 25.51 & 1.31 & 23.07 & 12.98 & 852.50 & 1205.50 & 41.42 & 43.00 & 16.14 \\
\hline IR 102757A & 111.50 & 16.00 & 18.50 & 76.39 & 25.81 & 1.23 & 21.51 & 17.90 & 704.00 & 1022.00 & 40.64 & 48.00 & 16.61 \\
\hline IR 68897A & 117.00 & 14.00 & 14.00 & 96.38 & 34.03 & 1.11 & 28.09 & 15.12 & 387.50 & 795.50 & 32.78 & 26.50 & 8.08 \\
\hline IR 58025A & 124.50 & 12.50 & 12.50 & 91.13 & 27.60 & 1.22 & 26.45 & 14.03 & 390.50 & 988.00 & 28.38 & 31.50 & 8.07 \\
\hline G. Mean & 118.92 & 17.42 & 16.58 & 85.44 & 27.14 & 1.31 & 23.96 & 16.80 & 578.17 & 1158.71 & 32.21 & 40.58 & 12.60 \\
\hline C.D. & 7.05 & 5.24 & 3.77 & 2.03 & 0.86 & 0.04 & 0.52 & 1.50 & 101.34 & 198.79 & 5.85 & 5.57 & 1.53 \\
\hline $\mathrm{SE}(\mathrm{m})$ & 2.24 & 1.66 & 1.20 & 0.65 & 0.27 & 0.01 & 0.16 & 0.48 & 32.17 & 63.11 & 1.86 & 1.77 & 0.49 \\
\hline $\mathrm{SE}(\mathrm{d})$ & 3.17 & 2.35 & 1.69 & 0.91 & 0.39 & 0.02 & 0.23 & 0.67 & 45.50 & 89.26 & 2.63 & 2.50 & 0.69 \\
\hline C.V. & 2.66 & 13.50 & 10.20 & 1.07 & 1.43 & 1.51 & 0.97 & 4.00 & 7.87 & 7.70 & 8.16 & 6.16 & 5.46 \\
\hline
\end{tabular}


Table.2 Genetics parameters for different characters of 12 tested entries

\begin{tabular}{|c|c|c|c|c|c|c|}
\hline Characteristics & Range & Mean & PCV & GCV & Heritability (\%) & $\begin{array}{c}\text { Genetic } \\
\text { Advance }(\%)\end{array}$ \\
\hline Days to Flowering & $111-127$ & 118.92 & 226.21 & 35.61 & 2.48 & 11.55 \\
\hline No. of Tillers/plant & $13-24$ & 17.42 & 233.38 & 64.34 & 7.60 & 36.54 \\
\hline Productive Tillers/plant & $13-25$ & 16.58 & 213.74 & 145.51 & 46.35 & 204.07 \\
\hline Plant Height & $74-97$ & 85.44 & 194.97 & 93.71 & 23.10 & 92.78 \\
\hline Flag Leaf Length $(\mathrm{cm})$ & $21-34$ & 27.14 & 187.14 & 139.74 & 55.76 & 214.96 \\
\hline Flag Leaf Width & $1.1-1.5$ & 1.31 & 187.52 & 104.04 & 30.79 & 118.92 \\
\hline Panicle Length (cm) & $21-18$ & 23.96 & 213.35 & 145.43 & 46.46 & 204.21 \\
\hline No. of Panicle & $12-22$ & 16.80 & 206.65 & 163.20 & 62.37 & 265.52 \\
\hline Fertile Spikelet & $262-989$ & 578.17 & 245.81 & 224.62 & 83.51 & 422.84 \\
\hline Sterile spikelet & $796-1582$ & 1158.71 & 232.11 & 225.66 & 94.53 & 451.96 \\
\hline OCR \% & $18-45$ & 32.21 & 196.97 & 182.66 & 86.00 & 348.93 \\
\hline Biological weight (gm) & $27-56$ & 40.58 & 197.57 & 192.58 & 95.01 & 386.67 \\
\hline Grain weight (gm) & $4-21$ & 12.60 & 207.27 & 194.84 & 88.37 & 377.31 \\
\hline
\end{tabular}


Table.3 Genotypic and phenotypic correlation coefficients between yield and yield components in 12 CMS lines of rice

\begin{tabular}{|c|c|c|c|c|c|c|c|c|c|c|c|c|c|}
\hline & & 2 & 3 & 4 & 5 & 6 & 7 & 8 & 9 & 10 & 11 & 12 & 13 \\
\hline \multirow[t]{2}{*}{1} & GC & $1.137 * *$ & $1.915 * *$ & $1.535^{* *}$ & $2.346 * *$ & $2.530 * *$ & $1.660 * *$ & $1.899 * *$ & $2.194 * *$ & $2.800 * *$ & $2.709 * *$ & $2.034 * *$ & $2.872 * *$ \\
\hline & PC & $0.996 * *$ & $0.998 * *$ & $0.919 * *$ & $0.874 * *$ & $0.733 * *$ & $0.553 * *$ & $0.596 * *$ & $0.617 * *$ & $0.146 \mathrm{NS}$ & $-0.023 \mathrm{NS}$ & $0.474 *$ & $-0.122 \mathrm{NS}$ \\
\hline \multirow[t]{2}{*}{2} & GC & & $1.324 * *$ & $1.141 * *$ & $1.585^{* *}$ & $1.736 * *$ & $1.138 * *$ & $1.274 * *$ & $1.451 * *$ & $1.826 * *$ & $1.712 * *$ & $1.211 * *$ & $1.718 * *$ \\
\hline & PC & & $0.992 * *$ & $0.896 * *$ & $0.831 * *$ & $0.674 * *$ & $0.561 * *$ & $0.617 * *$ & $0.647 * *$ & $0.082 \mathrm{NS}$ & $-0.095 \mathrm{NS}$ & $0.530 * *$ & $-0.062 \mathrm{NS}$ \\
\hline \multirow[t]{2}{*}{3} & GC & & & $1.029 * *$ & $1.038 * *$ & $1.105^{* *}$ & $0.977 * *$ & $0.992 * *$ & $1.009 * *$ & $1.091 * *$ & $1.009 * *$ & $0.824 * *$ & $1.059 * *$ \\
\hline & PC & & & $0.940 * *$ & $0.890 * *$ & $0.757 * *$ & $0.595^{* *}$ & $0.629 * *$ & $0.644^{* *}$ & $0.194 \mathrm{NS}$ & $0.023 \mathrm{NS}$ & $0.479 *$ & $-0.173 \mathrm{NS}$ \\
\hline \multirow[t]{2}{*}{4} & GC & & & & $1.109 * *$ & $1.161 * *$ & $1.040 * *$ & $1.080 * *$ & $1.119 * *$ & $1.242 * *$ & $1.310 * *$ & $1.267 * *$ & $1.598 * *$ \\
\hline & PC & & & & $0.958 * *$ & $0.888 * *$ & $0.736^{* *}$ & $0.710 * *$ & $0.687 * *$ & $0.495^{*}$ & $0.334 \mathrm{NS}$ & $0.392 \mathrm{NS}$ & $-0.485^{*}$ \\
\hline \multirow[t]{2}{*}{5} & GC & & & & & $1.023 * *$ & $1.080 * *$ & $1.067 * *$ & $1.033 * *$ & $1.025 * *$ & $0.980 * *$ & $0.942 * *$ & $1.150 * *$ \\
\hline & PC & & & & & $0.970 * *$ & $0.543 * *$ & $0.495^{*}$ & $0.458^{*}$ & $0.553 * *$ & $0.445^{*}$ & $0.146 \mathrm{NS}$ & $-0.528 * *$ \\
\hline \multirow[t]{2}{*}{6} & GC & & & & & & $1.185^{* *}$ & $1.173 * *$ & $1.120 * *$ & $1.065^{* *}$ & $1.103 * *$ & $1.236 * *$ & $1.482 * *$ \\
\hline & PC & & & & & & $0.490 *$ & $0.400 \mathrm{NS}$ & $0.337 \mathrm{NS}$ & $0.705^{* *}$ & $0.635^{* *}$ & $-0.031 \mathrm{NS}$ & $-0.678 * *$ \\
\hline \multirow[t]{2}{*}{7} & GC & & & & & & & $1.006 * *$ & $1.032 * *$ & $1.159 * *$ & $1.219 * *$ & $1.107 * *$ & $1.374 * *$ \\
\hline & PC & & & & & & & $0.975^{* *}$ & $0.948 * *$ & $0.515^{*}$ & $0.306 \mathrm{NS}$ & $0.680 * *$ & $-0.502^{*}$ \\
\hline \multirow[t]{2}{*}{8} & GC & & & & & & & & $1.012 * *$ & $1.113^{* *}$ & $1.103 * *$ & $0.936 * *$ & $1.164 * *$ \\
\hline & PC & & & & & & & & $0.992 * *$ & $0.377 \mathrm{NS}$ & $0.141 \mathrm{NS}$ & $0.805^{* *}$ & $-0.317 \mathrm{NS}$ \\
\hline \multirow[t]{2}{*}{9} & GC & & & & & & & & & $1.049 * *$ & $0.982 * *$ & $0.814 * *$ & $1.001 * *$ \\
\hline & $\mathbf{P C}$ & & & & & & & & & $0.263 \mathrm{NS}$ & $0.022 \mathrm{NS}$ & $0.862 * *$ & $-0.211 \mathrm{NS}$ \\
\hline \multirow[t]{2}{*}{10} & GC & & & & & & & & & & $0.915 * *$ & $0.846 * *$ & $1.000 * *$ \\
\hline & $\mathbf{P C}$ & & & & & & & & & & $0.966 * *$ & $-0.137 \mathrm{NS}$ & $-0.890 * *$ \\
\hline \multirow[t]{2}{*}{11} & GC & & & & & & & & & & & $1.051 * *$ & $1.138 * *$ \\
\hline & $\mathbf{P C}$ & & & & & & & & & & & $-0.368 \mathrm{NS}$ & $-0.900 * *$ \\
\hline \multirow[t]{2}{*}{12} & GC & & & & & & & & & & & & $1.013 * *$ \\
\hline & PC & & & & & & & & & & & & $0.272 \mathrm{NS}$ \\
\hline
\end{tabular}


It is concluded that IR $102760 \mathrm{~A}$ found best CMS lines with highest OCR \% and yield per plant. It means such type of CMS line will be suitable for hybrid seed program and profitable in hybrid rice seed business followed by IR 105688A, IR 102757A, IR 105687A and IR 102571A may also be a promising CMS lines for hybrid rice seed program and heterosis breeding.

\section{Acknowledgement}

Research material 12 CMS lines provided by International Rice Research Institute, Manila, Philippines. We are thankful to Head - Hybrid Rice Development Consortium (HRDC), Project Leader and Coordinator for Asia \& East South Asia - Green Super Rice (GSR), IRRI, Philippines for their kind support.

\section{References}

Abeysekera, S. W. Abeysiriwardana, D. S. and Dehideniyz, E. 2003. Characteristics associated with outcrossing rate of cytoplasmic male sterile CMS lines in rice under local conditions. Annals of the Sri Lanka Department of Agriculture. 5:1-6.

AthwaI, D.S. and Virmani, S.S. 1972. Cytoplasmic male sterility and hybrid breeding in rice. In: Rice Breeding. IRRI, Manila, Philippines, pp. 615-620.

Dhanraj, A. Jagadish, C.A. Vigay, U. 1987. Studies on character association in the $\mathrm{F}_{2}$ generation on ten selected crosses in rice (Oryza sativa L.). J Res, APAU. 15(1):64-65.

Eusebio W., Casal C., Parado B., Bart Olome V., Virmani S. and McLaren G. 2002. Variations in frequency of maintainers and restorers in test crosses of the hybrid rice breeding programme. Philipp. J. Crop Sci. 27, suppl 1, 80.

Hasan, M.J. Ummakuisum, D. Rahman, M.H Hazratali, M. and Julfiquar, A.W. 2011.
Genetic variability of some cytoplasmic male sterile lines (CMS) of rice (Oryza sativa L.) genotypes Bangladesh J.Agril.Res 36:263-270.

Islam M.A., Mian M.A., Rasul G., Khaliq Q.A., Bashar M.K. 2014. Estimation of specific combining ability (SCA) effects and per-se performances in some reproductive traits in rice (Oryza sativa L.). Bangladesh Journal of Genetics and Plant Breeding 33:12-16.

Islam M.A., Mian, M.A.K., Rasul G., Johora, Sarker U.K. 2010. Interaction effect between genotypes, row ratio and fertilizer dose on hybrid seed production of rice (Oryza sativa. L.). Bangladesh Society of Agronomy 4:134-141.

Islam M.A., Sarker U.K., Mian M.A.K., Ahmed J.U. 2009. Genotype Seedling age Interaction for hybrid seed yield of rice (Oryza sativa. L.). Bangladesh Journal of Genetics and Plant Breeding 24:23-26.

Lin, S.C. and Yuan, L.P. 1980. Hybrid rice breeding in China. In Innovative Approaches to Rice Breeding. Int. Rice Res. Inst. Manila, Philippines. pp. 35 51.

Luat,V. Hoang, T.M. and Nguyen, V.S. 1994. Hybrid rice research in Vietnam In: Hybrid Rice Technology: New Developments and Future Prospects. Int. Rice Res. Inst., Manila, Philippines. pp. 187-193.

Maurya, D.M., Singh, S. K and Singh, R. S. 1986. Genetic variability in 48 low land rice cultivars of Uttar Pradesh, India. Int. Rice Res. Newsletter 11(4): 13.

Mian M.A.K. 2010. Hybrid rice breeding. Breeding for self-pollinated crops, Heterosis Breeding. BSMRAU, summer.

Sharma, H.L. 1995. Practice of hybrid rice production technology paper submitted at the hybrid rice seed production 
training course. International Rice Research Institute, Philippines.

Sheeba, A. Vivekanandan, P. and Ibrahim,S.M.2006. Genetic variability for floral traits influencing out crossing in the CMS lines of rice. Indian J.Agric.Res. 40(4):272-276.

Sheeba, N.K. Viraktamath, B, C., Sivaramakrishnan, S., Gangashetti, M. G., Khera, P. and Sundaram, R. M. 2009. Validation of molecular markers linked to fertility restorer gene(s) for WA-CMS lines of rice. Euphytica 167 pp. 217-227.

Singh, S., Sahu, H. and Sahu, P.K. 2015. Variability and genetic parameters for grain yield in CMS based rice hybrid (Oryza sativa L.). Journal of Plant Development Sciences Vol. 7 (3): 247 250.

Virmani, S.S., Viraktamath, B, C., Casal, C.L. Toledo, R.S., Lopez, M.T. and Manalo, J.O. 1997 Hybrid rice breeding manual-
HR2-01. International Rice Research Institute, Los, Banos, Lagona, Philippines. PP. 43.

Virmani,S.S.1994. Heterosis and hybrid rice breeding. Out crossing mechanisms and hybrid seed production practices in rice. Int. Rice Res Institute, Manila, Philippines. pp 79 -96.

Yuan, L P. 1998. Hybrid rice breeding in China. In: Virmani SS, Siddiq EA, Muralidharan K. (editors). Advances in hybrid rice technology. Proceedings of the $3^{\text {rd }}$ International Symposium on Hybrid Rice, 14-16 November 1996. Hyderabad, India. Manila (Philippines): International Rice Research Institute. pp 27-33.

Yuan, L.P. 1998. Genetic relationship of stigma exterior between maintainer lines and sterile lines for Dian type japonica hybrid rice. Journal-ofYunnan-Agricultural-University $\quad 20$ $459-461,477$.

\section{How to cite this article:}

Satyapal Singh, Deepak Sharma, Ritesh Singh, Jauhar Ali and Deepak Gauraha. 2020. Identification of Promising IRRI CMS Lines through OCR in Chhattisgarh, India. Int.J.Curr.Microbiol.App.Sci. 9(07): 320-328. doi: https://doi.org/10.20546/ijcmas.2020.907.034 